ISSN 0215-1790

MGI Vol. 29, No. 2, September 2015 (172-176).

(C) 2015 Fakultas Geografi UGM

\title{
ERRATA:
}

\section{KERANGKA ASET RUMAH TANGGA MISKIN DALAM PERISTIWA BANJIR PASANG SURUT DI KECAMATAN PEKALONGAN UTARA KOTA PEKALONGAN}

Novi Maulida Ni'mah', Djarot Sadharto ${ }^{2}$, dan Djati Mardiatno ${ }^{3}$

Fakultas Geografi, Universitas Gadjah Mada, Yogyakarta, Indonesia ${ }^{1,2,3}$

novimaulidanik'mah@gmail.com

Di naskah asli tertulis email: novimaulidanik'mah@gmail.com,

seharusnya yang benar adalah novimaulida@sttnas.ac.id. 